\title{
KOMPARASI SYARAT KEABSAHAN “SEBAB YANG HALAL" DALAM PERJANJIAN KONVENSIONAL DAN PERJANJIAN SYARIAH
}

\author{
Tri Wahyu Surya Lestari \\ Email:suryalestaripowers@gmail.com \\ Lukman Santoso/ 085643210185 \\ Institut Agama Islam Negeri Ponorogo \\ Email: lukmansantoso4@gmail.com
}

\begin{abstract}
Social relation is a basic need for human beings in the society. Since members of the society are coming from various backgrounds, there should be rules or regulations to be followed by the members of the society. The rules aim at creating safety and comfort in the society and also maintaining a good and harmonious social relation. One of the rules is agreement. There are 3 sub-systems of law in Indonesia i.e. Western Law, Customary Law and Islamic Law. Prior to an agreement, there are requirements needed to be fulfilled so the agreement can be effective as a rule. One of the requirements is "legal cause" which should be studied further by each side due to some differences in conventional agreement and agreement based on Islamic Law in order to prevent unnecessary misunderstanding.
\end{abstract}

Keywords: agreement, law, requirement

Abstrak

Sebagai makhluk sosial, hubungan bermasyarakat ialah hal mendasar dan tak terpisahkan. Pergaulan masyarakat yang memiliki banyak perbedaan mengharuskan adanya suatu pedoman khusus atau hukum yang dianut masyarakat tersebut. Hukum tersebut ialah demi mewujudkan rasa aman dan terjamin dalam menjalin hubungan bermasyarakat, serta untuk mewujudkan hubungan bermasyarakat yang baik, harmonis dan tanpa harus merugikan orang lain. Bentuk pedoman khusus dalam masyarakat diantaranya ialah perjanjian. Indonesia memiliki 3 sub sistem hukum yang secara garis besar terbagi menjadi yakni hukum barat, hukum adat, dan hukum Islam. Pengadaan perjanjian dalam rangka meningkatkan rasa aman dan kepastian sudah seperti tidak terelakkan dalam zaman modern yang semakin pesat perkembangannya seperti saat ini. Karena itu, sebelum 
melaksanakan sebuah perjanjian, perlu dipenuhinya segala syarat keabsahan perjanjian agar perjanjian tersebut dapat berlaku sebagai undang-undang, sehingga tujuan diadakannya perjanjian dapat tercapai. Salah satu dari syarat keabsahan perjanjian yakni "sebab yang halal" adalah hal yang penting untuk dikaji secara dalam oleh para pihak yang mengadakan perjanjian karena adanya perbedaan sistem hukum dalam lingkungannya (Indonesia) utamanya sistem perjanjian konvensional yang dijadikan patokan perundang-undangan di Indonesia dan sistem perjanjian Islam atau syariah yang dijadikan pedoman mayoritas rakyat Indonesia yang beragama Islam, agar tidak terdapat hal-hal yang tidak ingin ditimbulkan di kemudian hari.

Kata kunci: sebab yang halal, perjanjian konvensional, perjanjian syariah.

\section{A. PENDAHULUAN}

Pergaulan hidup antar manusia tidak dapat dipisahkan dari pola dan mekanisme-mekanisme tertentu yang tumbuh dan berkembang, disepakati dan ditetapkan sebagai pedoman hidup masyarakat. Semakin kompleks suatu masyarakat, semakin kompleks pula hal-hal yang mesti diatur dan disepakati untuk menjaga keseimbangan hidup antarwarga masyarakat, termasuk untuk membangun masyarakat yang bersangkutan (Lukman Santoso Az, 2016:2-3). Kesepakatan kesepakatan tersebut nantinya akan meningkat menjadi perjanjian sampai dengan pelaksanaan perjanjian itu sendiri (Martha Eri Safira, 2016:83).

Istilah perjanjian merupakan terjemahan dari kata overeenkomst yang berasal dari bahasa Belanda atau contract yang berasal dari bahasa Inggris (Dona Budi Kharisma, 2013:11). Menurut Santoso AZ definisi dari perjanjian sendiri, secara etimologis di definisikan sebagai suatu persitiwa dimana seorang berjanji kepada orang lain atau dimana dua orang itu saling berjanji untuk melaksanakan sesuatu hal. Sedangkan dalam Kamus Besar Bahasa Indonesia, perjanjian adalah persetujuan tertulis atau dengan lisan yang dibuat oleh dua pihak atau lebih, masing-masing bersepakat akan menaati apa yang tersebut dalam persetujuan itu. Menurut Subekti, suatu perjanjian merupakan suatu peristiwa di mana seseorang berjanji kepada orang lain, atau di mana dua orang saling berjanji untuk melaksanakan suatu hal.( Giska Matahari Gegana, 2011: 19). Menurut Abdulkadir Muhammad, 
"perjanjian adalah suatu persetujuan dengan mana dua orang atau lebih saling mengikatkan diri untuk melaksanakan suatu hal dalam lapangan harta kekayaan" (Giri Prasadha, 2015:5-6). Menurut R. Wirjono Projodikoro, "perjanjian adalah suatu perhubungan hukum mengenai harta benda antara dua pihak, dalam mana satu pihak berjanji atau dianggap berjanji untuk melakukan sesuatu hal, sedangkan pihak lain berhak menuntut pelaksanaan janji itu" Dita Rahmasari (Dita Rahmasari,2011: 1213). Van Dunne mengartikan perjanjian sebagai suatu hubungan hukum antara dua pihak atau lebih berdasarkan kata sepakat untuk menimbulkan akibat hokum (Novina Sri Indraharti, 2014: 18). Menurut Hendi Suhendi perjanjian adalah suatu hubungan hukum di lapangan harta kekayaan dimana seseorang berjanji (dianggap berjanji) kepada seseorang yang lain atau kedua pihak saling berjanji untuk melakukan sesuatu atau tidak melakukan sesuatu.( http://jondrapianda.blogspot.co.id.

Tujuan dari adanya hukum perjanjian diharapkan dapat meningkatkan kepastian, keadilan, dan prediktabilitas (predictability) dan pada saat yang bersamaan menjadi alat bagi para pihak untuk mengelola risiko (risk management tool) (Gayo, 2015: 486). Karena besarnya harapan atau tujuan yang ingin dicapai melalui adanya perjanjian tersebut, maka segala hal yang mendukung berjalannya suatu perjanjian harus diperhatikan secara cermat dan dipersiapkan secara matang. Salah satu diantara yang perlu diperhatikan ialah dari segi syarat dari keabsahan perjanjian. Sebagaimana telah disebutkan di dalam ketentuan pasal 1338(1) KUHPerdata bahwa seketika perjanjian telah memenuhi syarat bagi keabsahan kontrak, maka kontrak demikian berlaku sebagai hukum bagi para pihak yang membuatnya (Rosa Agustina dkk, 2012: 85). Selanjutnya, dalam pasal 1320 KUHPerdata, supaya terjadi persetujuan yang sah, perlu dipenuhi empat syarat: kesepakatan mereka yang mengikatkan dirinya, kecakapan untuk membuat suatu perikatan, suatu pokok persoalan tertentu, suatu sebab yang tidak terlarang. Hal tersebut menunjukkan bahwa pemenuhan ke empat syarat ialah sangat penting dan mendasar demi mewujudkan suatu perjanjian yang sah. Tanpa pemenuhan ke empat syarat tersebut, maka 
dapat dipastikan bahwa suatu perjanjian dianggap sebagai suatu perjanjian yang tidak sah.

Dalam konteks hukum, perjanjian masuk ke dalam ranah hukum privat umum, yaitu hukum yang mengatur hubungan antara orang yang satu dengan orang yang lain, dengan menitik beratkan pada kepentingan perorangan atau individu. Istilah hukum privat dalam sistem hukum Indonesia disebut juga hukum Perdata (Santoso Az, 2016: 4). Hukum perdata yang mengatur mengenai hubungan antar sesama manusia merupakan peninggalan Pemerintah Hindia Belanda. Pedoman politik bagi Pemerintah Hindia Belanda terhadap hukum di Indonesia dituliskan dalam pasal 131 Indische Staatsregeling atau biasa disingkat dengan IS. Hasil kodifikasi atas hukum perdata yang berupa KUHPerdata sampai saat ini masih berlaku sebagai pedoman hukum materiil di Indonesia. Dasar hukum berlakunya KUHPerdata adalah Pasal 1 Aturan Peralihan Undang-Undang Dasar Negara Republik Indonesia 1945 (UUD NRI 1945) yang menyatakan bahwa "segala peraturan perundang-undangan yang ada masih tetap berlaku selama belum diadakan yang baru menurut Undang-Undang Dasar ini" Berdasarkan hal tersebut, bahwa KUHPerdata yang menganut sistem barat sebagai sistem yang dianut negara pembawanya yakni Belanda, berdampak pada penyebutan istilah perjanjian yang menganut dasar hukum KUHPerdata sebagai perjanjian konvensional. Selain sistem barat atau sistem konvensional tersebut, di Indonesia juga berlaku sistem hukum Islam. Berlakunya hukum Islam di Indonesia telah mengalami pasang surut seiring dengan politik hukum yang diterapkan oleh kekuasaan negara. Sampai saat ini, kedudukan hukum Islam dalam sistem hukum di Indonesia semakin memperoleh pengakuan yuridis (Dwi Ratna Indri Hapsari, 2014: 84), yaitu diantaranya pada tataran peraturan perundang-undangan seperti Undang-undang Nomor 21 Tahun 2008 tentang Perbankan Syariah, Undang-Undang Nomor 3 Tahun 2006 sebagaimana dirubah dengan Undang-Undang Nomor 50 Tahun 2009 tentang Perubahan kedua atas Undang-Undang Nomor 7 Tahun 1989 tentang Peradilan Agama, terjadi perubahan berupa penambahan kewenangan sebagaimana bunyi Pasal 49: "Pengadilan Agama bertugas dan berwenang memeriksa, memutus dan menyelesaikan perkara ekonomi 
Syariah, Undang-Undang Nomor 13 Tahun 2008 Tentang Penyelenggaraan Ibadah Haji, Undang-Undang Nomor 23 Tahun 2011 tentang Pengelolaan Zakat, Undang-undang tentang Penyelenggaraan Haji, ketentuan mengenai pasar modal, dan gadai.(Akhyar Ari Gayo, 2015: 487). Di Indonesia, hukum-hukum agama Islam dikenal dengan sebutan syari'at, fiqih, dan hukum islam. ( Akhyar Ari Gayo, 2015: 490). Sehingga dalam hal ini perjanjian yang menggunakan hukum Islam sebagai dasar hukumnya disebut dengan perjanjian syariah.

Karena adanya dua sub sistem hukum di Indonesia tersebut, baik yang diatur dalam KUHPerdata maupun dalam hukum Islam atau secara syariah dan pentingnya pemenuhan syarat keabsahan perjanjian agar perjanjian mampu berlaku sebagai hukum, perlu diadakan penafsiran yang jelas utamanya pada syarat sebab yang tidak terhalang atau sebab yang halal, karena menurut penulis, penyebutan kata "halal" tersebut sangat sentimentil dan perlu ditafsirkan secara gamblang baik dari sisi perjanjian konvensional maupun dari sisi perjanjian syariah atau perjanjian secara hukum Islam. Melalui pengkajian ini maka artikel ini berusaha mengupas hal yang berkaitan syarat keabsahan perjanjian yaitu mengenai apa saja syarat keabsahan perjanjian dalam perjanjian konvensional dan perjanjian syariah? Melalui perbandingan perjanjian konvensional dan perjanjian syariah tersebut, apakah ada hal berbeda dalam penerapan syarat keabsahan "sebab yang halal" dalam kedua jenis perjanjian tersebut? Hal ini yang mendorong minat penulis di dalam melakukan kajian tersebut.

\section{B. KONSEP SYARAT KEABSAHAN PERJANJIAN DALAM PERJANJIAN}

Hukum kontrak atau perjanjian di Indonesia masih menggunakan peraturan pemerintah kolonial Belanda yang terdapat dalam Buku III Burgerlijk Wetboek. (Muhammad Noor,2015: 90). Karenanya secara konvensional, dalam pasal 1313 KUHPerdata, suatu persetujuan adalah suatu perbuatan dimana satu orang atau lebih mengikatkan diri terhadap satu orang lain atau lebih. Dalam KUHPerdata, Pasal 1320 menyebutkan syarat yang diperlukan untuk sahnya suatu perjanjian; sepakat mereka yang mengikatkan dirinya, 
kecakapan untuk membuat suatu perikatan, suatu hal tertentu, suatu sebab yang halal (Carina Pariska Pribadi, 2013-2014: 28)

1. Sepakat mereka yang mengikatkan dirinya

Maksudnya bahwa para pihak yang membuat perjanjian telah sepakat atau setuju mengenai hal-hal pokok dari perjanjian yang dibuat. Kesepakatan itu dianggap tidak ada apabila sepakat itu diberikan karena kekeliruan / kekhilafan atau diperolehnya dengan paksaan atau penipuan (Sylviana, 2009: 14).

Menurut KUHPerdata, suatu paksaan yang dapat mengakibatkan pembatalan suatu perjanjian haruslah memenuhi syarat sebagai berikut:

a. Paksaan dilakukan terhadap (pasal 1325):

- Orang yang membuat perjanjian;

- Suami atau istri dari orang yang membuat perjanjian;

- Sanak keluarga dalam garis keturunan ke atas atau ke bawah.

b. Paksaan dilakukan oleh:

- $\quad$ Salah satu pihak dalam perjanjian;

- $\quad$ Pihak ketiga untuk kepentingan siapa perjanjian tersebut dibuat.

c. Paksaan tersebut menakutkan seseorang.

d. Orang yang takut tersebut harus berpikiran sehat.

e. Ketakutan sebagai akibat paksaan itu berupa:

- Ketakutan terhadap diri orang tersebut;

- Ketakutan terhadap kerugian yang nyata dan terang terhadap harta kekayaan orang yang bersangkutan.

f. Timbulnya ketakutan karena paksaan haruslah dengan mempertimbangkan keadaan dari yang dipaksakan berupa:

- Usia;

- Kelamin;

- Kedudukan.

g. Ketakutan bukan karena hormat dan patuh kepada orang tua atau sanak keluarga tanpa paksaan. (pasal 1326 KUHPerdata)

h. Pembatalan suatu perjanjian berdasarkan paksaan tidak lagi dapat dituntut, apabila setelah terjadi paksaan, perjanjian tersebut telah dikuatkan baik secara tegas 
ataupun diam-diam. (pasal 1327 KUHPerdata) ( M.P. Hutabarat: 37 ).

2. Kecakapan untuk membuat suatu perikatan

Yang dimaksud dengan cakap disini adalah orang yang sudah dewasa, sehat akal pikiran dan tidak dilarang oleh suatu perundang-undangan untuk melakukan suatu perbuatan tertentu. Orang-orang yang dianggap tidak cakap dalam melakukan perbuatan hukum yaitu:

a. Orang-orang yang belum dewasa.

Menurut pasal 1330 KUHPer jo. Pasal 47 UU No.

1 / 1974 tentang Perkawinan, orang belum dewasa adalah anak dibawah umur 18 tahun, atau belum pernah melangsungkan pernikahan.

b. Orang-orang yang ditaruh dibawah pengampuan.

Menurut pasal 1330 jo. Pasal 433 KUHPer yaitu orang yang telah dewasa tetapi dalam keadaan dungu, gila, mata gelap dan pemboros.

c. Orang-orang yang dilarang dalam undang-undang untuk melakukan perbuatan hukum tertentu.

Misalnya, orang yang telah dinyatakan pailit oleh Pengadilan.(Panduan Bantuan Hukum di Indonesia 2006:133).

3. Mengenai suatu hal tertentu

Yang dimaksud mengenai suatu hal tertentu, artinya ialah apa yang akan diperjanjikan harus jelas dan terinci (jenis, jumlah dan harga) atau keterangan terhadap objek, diketahui hak dan kewajiban tiap-tiap pihak, sehingga tidak terjadi suatu perselisihan antara para pihak.

4. Suatu sebab (kausa) yang halal

Kata kausa yang diterjemahkan dari kata oorzaak (Belanda) atau causa (Latin) yang dimaksudkan dalam hal perjanjian ini bukan berarti sesuatu yang menyebabkan seseorang membuat perjanjian, tetapi mengacu kepada isi dan tujuan perjanjian itu sendiri. Misalnya dalam perjanjian jual beli, isi dan tujuan atau kausanya adalah pihak yang satu menghendaki hak milik suatu barang, sedangkan pihak lainnya menghendaki uang (R.M. Panggabean, 2010: 658).

Hal-hal yang dimaksud dengan sebab yang halal dalam perjanjian, diantaranya adalah sebagai berikut: 
a. Klausa yang halal berarti isi dari perjanjian itu tidak bertentangan dengan ketertiban umum, kesusilaan, dan undang-undang (Fajar Bayu Setiawan, Dkk, 2013: 70).

Norma kesusilaan menjadi ukuran yang penting dalam menilai tindakan memenuhi kriteria kesusilaan (tindakan susila) ataukah tindakan tidak memenuhi kriteria kesusilaan (tindakan asusila). Sundari menjelaskan hakikat hukum sebagai “... suatu sistem norma karya manusia yang penuh kekurangan karena tergantung pada waktu dan tempat sehingga sifatnya tidak selesai dan tidak dapat selesai". Pernyataan tersebut menunjukkan bahwa pemaknaan norma kesusilaan dapat berkemungkinan mengalami perbedaan persepsi, dan pemahaman akan sejauh mana norma kesusilaan itu berlaku juga mengalami perkembangan dari waktu ke waktu (Hwian Christianto, 2016: 8-9). J. Satrio memaknai ketertiban umum sebagai hal-hal yang berkaitan dengan masalah kepentingan umum, keamanan negara, keresahan dalam masyarakat, dan karenanya dapat dikatakan berkaitan masalah ketatanegaraan.

b. Sebab dikatakan palsu jika diadakan untuk menutupi sebab yang sebenarnya.

c. Sebab dikatakan terlarang jika bertentangan dengan undang-undang, kesusilaan, dan ketertiban umum.

Misalnya, tidak dipenuhinya ketentuan pasal 31 ayat (1) UU No. 24 / 2009 dapat dikategorikan sebagai suatu bentuk pelanggaran dalam undang-undang. Oleh karena itu, tidak digunakannya Bahasa Indonesia dalam perjanjian yang melibatkan pihak asing dapat dijadikan alasan bagi salah satu pihak untuk meminta perjanjian dinyatakan "Batal Demi Hukum", dengan alasan perjanjian tidak memenuhi syarat sah pada pasal 1320 yaitu "suatu sebab yang halal"( Buletin Len,2014: 50).

d. Suatu perjanjian tanpa sebab, jika tujuan yang dimaksudkan oleh para pihak pada saat dibuatnya perjanjian tidak akan tercapai (Eka Astri Maerisa, 2013: 06).

Dari ke empat syarat keabsahan perjanjian yang telah dijabarkan di atas, syarat sahnya perjanjian tersebut oleh 
R.Subekti dikelompokkan dalam dua kelompok, yaitu syarat yang bersifat subjektif dan syarat yang bersifat objektif. Syarat subjektif, yaitu kelompok syarat-syarat yang berhubungan dengan subyeknya dikelompokkan secara garis besar sebagai kesepakatan dan kecakapan. Syarat objektif, yaitu kelompok syarat-syarat yang berhubungan dengan objeknya dikelompokkan secara garis besar sebagai hal tertentu dan sebab yang halal. Perbedaan syarat-syarat sahnya perjanjian dalam dua kelompok ini digunakan untuk mengetahui apakah perjanjian itu batal demi hukum (void ab initio) atau merupakan perjanjian yang dapat dimintakan pembatalan (voidable) (Dita Rahmasari, 2011:25). Jika yang dilanggar ialah syarat objektif maka perjanjian yang telah dibuat adalah batal demi hukum yang berarti tanpa diminta pembatalannya, dianggap tidak pernah ada. Berbeda dengan dilanggarnya syarat subjektif yang tetap dinyatakan berlaku hingga dimintakan pembatalan (http://www.jurnalhukum.com/syarat-syarat-sahnyaperjanjian).

Dengan dipenuhinya ke empat syarat tersebut, maka suatu perjanjian menjadi sah dan mengikat secara hukum bagi para pihak yang membuatnya. Pihak-pihak yang berjanji itu harus bermaksud supaya perjanjian yang mereka buat itu mengikat secara sah. Pengadilan harus yakin tentang maksud mengikat secara sah itu. Mengikat secara sah artinya perjanjian menimbulkan hak dan kewajiban bagi pihak-pihak yang diakui oleh hukum (Evalina Yessica,2014:50).

Dalam hukum Islam, akad atau kontrak berasal dari bahasa Arab yang berarti ikatan atau simpulan baik ikatan nampak (hissy) maupun tidak nampak (ma'nawy). Sedangkan akad menurut istilah adalah suatu kesepakatan atau komitment bersama baik lisan, isyarat, maupun tulisan antara dua pihak atau lebih yang memiliki implikasi hukum yang mengikat untuk melaksanakannya. Kontrak disebut juga akad atau perjanjian yaitu bertemunya ijab yang diberikan oleh salah satu pihak dengan kabul yang diberikan oleh pihak lainnya secara sah menurut hukum syar'i dan menimbulkan akibat pada subyek dan obyeknya (Emanuel Raja Damaitu,2014:62).

Rumusan akad di atas mengindikasikan bahwa perjanjian harus merupakan perjanjian kedua belah pihak untuk mengikatkan diri tentang perbuatan yang akan 
dilakukan dalam suatu hal yang khusus. Akad ini diwujudkan, pertama, dalam ijab dan qabul. Kedua, sesuai dengan kehendak syariat. Ketiga, adanya akibat hukum pada objek perikatan (Emanuel Raja Damaitu,2015: 493).

Kaidah-kaidah hukum yang berhubungan langsung dengan konsep hukum kontrak dalam hukum Islam disini, adalah yang bersumber dari al-Quran dan hadist maupun hasil interpretasi terhadap keduanya, serta kaidah-kaidah fiqih. Dalam hal ini dapat digunakan juga kaidah-kaidah hukum yang terdapat di dalam Qanun yaitu peraturan perundangundangan yang telah diundangkan oleh pemerintah baik pusat maupun daerah dan yurisprudensi, serta peraturan-peraturan hukum yang tidak bertentangan dengan hukum Islam (Hapsari ,2014:86).

Menurut Lukman Santoso dalam bukunya yang berjudul "Hukum Perikatan: Teori Hukum dan Teknis Pembuatan Kontrak, Kerja sama, dan Bisnis" rukun dan syarat perjanjian syariah terdiri dari 4 syarat, yaitu:

1. Pernyataan kehendak para pihak/ ijab qabul.

Menurut Wahbah Zuhaili, ada tiga syarat yang harus dipenuhi agar suatu ijab dan qabul dipandang sah serta memiliki akibat hukum, yakni jala'ul ma'na, tawafuq, dan jazmul iradataini. Jala'ul ma'na berarti bahwa tujuan yang terkandung dalam pernyataan suatu perjanjian itu harus jelas, sehingga dari pernyataan tersebut dapat dipahami jenis kontrak yang dikehendaki. Sedangkan yang dimaksud dengan tawafuq adalah antara ijab dan qabul harus memiliki kesesuaian. Dan terakhir ialah jazmul iradataini, yaitu antara ijab dan qabul menunjukkan kehendak para pihak secara pasti, tidak ada keraguan sedikitpun, tidak berada di bawah tekanan dan tidak berada dalam keadaan terpaksa.

Kriteria dari pelaku kontrak disyaratkan harus mukhallaf (aqil baligh, berakal sehat, dewasa dan cakap hukum). Para ahli hukum Islam sepakat bahwa batasan umur pelaku kontrak diserahkan kepada 'urf (adat) setempat dan atau undang-undang yang berlaku dalam suatu negara.

2. Objek kontrak / mahal al 'Aqd. 
Para ahli hukum Islam sepakat bahwa sesuatu obyek kontrak harus memenuhi empat syarat: Pertama, kontrak harus sudah ada secara konkrit ketika kontrak dilangsungkan atau diperkirakan akan ada pada masa akan datang. Dalam kontrak-kontrak tertentu ketentuan ini dapat dibenarkan seperti kontrak salam (pesan barang dengan pembayaran harga sebagian atau seluruhnya lebih dahulu), kontrak ijarah/ leasing (sewa menyewa), atau juga dalam bentuk bagi hasil (mudharabah), dimana obyek akad cukup diperkirakan akan ada pada masa yang akan datang. Kedua, dibenarkan oleh syara', sehingga segala hal yang tidak bersesuaian atau bertentangan dengan syara' tidak dapat dijadikan sebagai objek kontrak. Ketiga, kontrak harus dapat diserahkan ketika terjadi kontrak, namun tidak harus diserahkan secara seketika, yakni dapat dimungkinkan untuk diserahkan pada saat yang telah ditentukan dalam kontrak. Ke empat, kontrak harus jelas atau dapat ditentukan (mu'ayyan) dan harus diketahui oleh kedua belah pihak yang membuat kontrak.

3. Pihak-pihak yang melaksanakan kontrak / al 'aqidain.

Pihak-pihak yang melaksanakan kontrak disebut dengan subyek hukum. Subyek hukum ini saling memiliki hubungan hak dan kewajiban. Dalam hukum Islam tidak semua orang dapat melaksanakan sendiri hak dan kewajibannya dan keadaan ini disebut dengan "mahjur 'alaih" sebagaimana tersebut dalam al-Qur'an surat an-Nisa ayat 5 yang artinya 5 "janganlah kamu serahkan kepada orangorang yang belum sempurna akalnya, harta (mereka yang ada dalam kekuasaanmu) yang dijadikan Allah sebagai pokok kehidupan". Berdasarkan hal tersebut diatas, dalam hukum Islam dikenal dengan orang yang tidak cakap bertindak dalam hukum yaitu mereka disebut dengan "asy-syufah".

Menurut Muhammad Ali as-Sayis sebagaimana dikutip oleh Hasbalah Thaib, yang dimaksud dengan asshufaha ialah orang yang tidak sempurna akalnya dalam hal memelihara hartanya dan kebaikan tasharruf padanya, yang dalam hal ini adalah anak-anak yang belum dewasa, orang gila dan orang yang selalu membuat mubazir atau berlebih-lebihan dalam hidupnya. Sejalan dengan pendapat Muhammad Ali as-Sayis, menurut Chairuman 
Pasaribu dan Suhrawardi K. Lubis, orang yang termasuk "mahjur 'alaih" adalah anak yang masih dibawah umur, orang yang tidak sehat akalnya dan orang yang boros yang selalu membuat mubazir dalam hidupnya.

4. Tujuan kontrak / maudhu'ul 'aqd.

Yang dimaksud tujuan kontrak / maudhu'ul 'aqd adalah untuk apa suatu kontrak dilakukan (al-maqshad al ashli alladzi syariah al 'aqd min ajlih) oleh seseorang dengan orang lain dalam rangka melaksanakan suatu muamalah antara manusia, dan yang menentukan akibat hukum dari suatu kontrak adalah al mysyarri' (yang menetapkan syariat) yakni Allah. Dengan kata lain, akibat hukum dari suatu kontrak harus diketahui melalui syara' dan harus sejalan dengan kehendak syara'. Atas dasar ini, semua kontrak yang bertentangan dengan syara' adalah tidak sah dan oleh karena itu tidak menimbulkan hubungan hukum.

Ahmad Azhar Basyir menentukan syarat-syarat yang harus dipenuhi agar suatu tujuan kontrak dipandang sah dan mempunyai akibat hukum, diantaranya yaitu tujuan kontrak bukanlah kewajiban yang telah ada atas pihak-pihak yang bersangkutan tanpa kontrak yang diadakan, yang berarti tujuan hendaknya baru ada pada saat akad diadakan dan bukan sebelum perjanjian diadakan, tujuan harus berlangsung sebagaimana adanya sampai berakhirnya pelaksanaan kontrak, serta tujuan kontrak harus dibenarkan oleh syara', jika syarat ini tidak terpenuhi maka kontrak dianggap sebagai tidak sah (Santoso Az, 2016:50-53).

\section{ANALISIS PERBANDINGAN SYARAT KEABSAHAN PERJANJIAN "SEBAB YANG HALAL"}

Dalam perjanjian konvensional, sebagaimana telah dipaparkan diatas, suatu sebab yang halal, berarti sesuatu yang menyebabkan seseorang membuat perjanjian, tetapi mengacu kepada isi dan tujuan perjanjian itu sendiri (Panggabean,2010: 658). Sedangkan dalam perjanjian syariah, sebab yang halal dikenal dengan istilah tujuan kontrak / maudhu'ul 'aqd yang berarti untuk apa suatu kontrak dilakukan (al-maqshad al ashli alladzi syariah al 'aqd min ajlih) oleh seseorang dengan orang lain dalam rangka melaksanakan suatu muamalah antara manusia, 
dan yang menentukan akibat hukum dari suatu kontrak adalah al mysyarri' (yang menetapkan syariat) yakni Allah sendiri (Santoso Az, 2015: 52) Baik dalam syarat "sebab yang halal" dalam perjanjian konvensional maupun "tujuan kontrak" dalam perjanjian syariah, keduanya sama-sama memberikan penekanan penting mengenai yang dimaksud dengan isi dari syarat tersebut yakni membahas tentang tujuan adanya suatu perjanjian.

Lebih lanjut dijelaskan, dalam perjanjian konvensional yang dimaksud dengan syarat klausa yang halal ialah apabila diantaranya yaitu: Pertama, dalam perjanjian tersebut tidak boleh bertentangan dengan ketertiban umum, kesusilaan, dan undang-undang (Setiawan,2013: 70). Kedua, sebab atau tujuan dikatakan palsu jika diadakan untuk menutupi sebab atau tujuan yang sebenarnya. Ketiga, sebab atau tujuan dikatakan terlarang jika bertentangan dengan undang-undang, kesusilaan, dan ketertiban umum (Buletin Len, 2014: 50). Keempat, suatu perjanjian dikatakan tanpa sebab atau tanpa tujuan, jika tujuan yang dimaksudkan oleh para pihak pada saat dibuatnya perjanjian tidak akan tercapai (Maerisa, 2013: 6). Dibandingkan dalam perjanjian syariah, tujuan kontrak seperti yang telah dijelaskan diatas menurut Ahmad Azhar Basyir, suatu tujuan kontrak dipandang sah dan mempunyai akibat hukum yaitu: pertama, tujuan kontrak tidak merupakan kewajiban yang telah ada atas pihak-pihak yang bersangkutan tanpa kontrak yang diadakan, tujuan hendaknya baru ada pada saat akad diadakan; kedua, tujuan harus berlangsung adanya hingga berakhirnya pelaksanaan kontrak; ketiga, tujuan kontrak harus dibenarkan olehh syara', jika syarat ini tidak terpenuhi maka kontrak tidak sah (Santoso Az, 2016: 52-53). Dari sini, semakin terlihat jelas perbedaan antara perjanjian konvensional dan perjanjian syariah dalam pemaknaan syarat keabsahan perjanjian "sebab yang halal / tujuan kontrak", bahwa dalam konvensional sumber patokan apakah sebab itu halal ataupun tidak ialah undang-undang, kesusilaan, dan ketertiban umum.

Sebagaimana yang telah dinyatakan oleh Sundari bahwa hakikat hukum sebagai “... suatu sistem norma karya manusia yang penuh kekurangan karena tergantung pada waktu dan tempat sehingga sifatnya tidak selesai dan tidak dapat selesai". Maka patokan tidak melanggar norma kesusilaan ini 
menimbulkan banyak penafsiran karena berbeda-beda antar wilayah, dan lagi, pemahaman akan sejauh mana norma kesusilaan itu berlaku juga mengalami perkembangan dari waktu ke waktu (Christianto, 2016: 8-9). Secara lebih dalam, ini tentu akan menimbulkan ketidak pastian hukum dikakibatkan tidak adanya pengaturan yang jelas, dilihat dari segi patokan norma kesusilaan. Sedangkan secara syariah, sumber patokan apakah sebab itu halal ataupun tidak ialah apabila dibenarkan olehh syara', sumber ini satu dan secara pasti memberi rasa aman kepada pelaku perjanjian syariah karena tidak adanya penafsiran-penafsiran lain dari segi patokan hukumnya.

Dilihat dari akibat hukumnya, Syarat sahnya perjanjian "sebab yang halal" dalam perjanjian konvensional, oleh R.Subekti dikelompokkan dalam kelompok syarat objektif, yaitu kelompok syarat-syarat yang berhubungan dengan objeknya (Dita Rahmasari, 2011:25), yang jika dilanggar maka perjanjian yang telah dibuat adalah batal demi hukum yang berarti tanpa diminta pembatalannya, dianggap tidak pernah ada. Sedangkan dalam perjanjian syariah, akibat hukum dari suatu kontrak adalah al mysyarri' (yang menetapkan syariat) yakni Allah sendiri ( Santoso Az, 2016: 52).

\section{Kesimpulan}

Sebenarnya baik secara konvensional maupun hukum Islam atau syariah, maksud diadakannya syarat keabsahan perjanjian berupa tujuan yang diatur sedemikian rupa adalah sama yakni untuk meningkatkan kepastian, keadilan, dan prediktabilitas (predictability) dan pada saat yang bersamaan menjadi alat bagi para pihak untuk mengelola risiko (risk management tool). Tapi memang, secara landasan hukum keduanya memiliki arah yang berbeda. Pada konvensional, segala sesuatunya diatur berdasarkan undang-undang yang paling utama baru kemudian adat yakni diantaranya adalah norma kesusilaan dan ketertiban umum. Dan pada perjanjian syariah, segala aturan baik dalam hal perjanjian maupun segala tingkah laku umat Islam harus berdasarkan landasan utama dan terutama, yakni syariah (hukum yang ditetapkan Allah), baik itu berupa al-Quran dan hadist maupun hasil interpretasi terhadap keduanya, serta kaidah-kaidah fiqih. Meskipun ada aturan yang mempertimbangkan norma adat ('urf), akan tetapi 
bila 'urf ini tidak sesuai dengan syara' maka tetap tidak boleh melangsungkan perjanjian berdasarkan 'urf tersebut. Apalagi dari segi akibat hukum, yang pada perjanjian konvensional apabila syarat "sebab yang halal" dilanggar maka perjanjian yang telah dibuat adalah batal demi hukum yang berarti tanpa diminta pembatalannya, dianggap tidak pernah ada. Sedangkan dalam perjanjian syariah, akibat hukum dari suatu kontrak adalah al mysyarri' (yang menetapkan syariat) yakni Allah sendiri, dan segala sesuatu dari tindakan manusia pasti akan ada pertanggung jawabannya. Wallahu a'lam.

Kiranya amat penting bagi para pihak untuk menentukan bentuk perjanjian apa yang akan dibuat sebelum mengadakan perjanjian sehingga terdapat satu pemahaman dan rasa nyaman dalam pelaksanaan perjanjian kedepannya. Perlu pula, sebagai salah satu sistem hukum besar di Indonesia, dan mayoritas rakyatnya yang menduduki posisi umat muslim terbesar di dunia, seharusnya pemerintah secara yuridis mengatur tentang perjanjian secara syariah dalam suatu undang-undang tersendiri, dan tidak lagi berdasarkan KUHPerdata sebagai rujukan dan dasar yang kuat untuk menjamin berlangsungnya perjanjian, terutama bagi masyarakat muslim di Indonesia. 


\section{DAFTAR PUSTAKA}

Agustina, Rosa, dkk. Hukum Perikatan (Law of Obligations). Ed.1. Denpasar: Pustaka Larasan; Jakarta: Universitas Indonesia, Universitas Leiden, Universitas Groningen, 2012.

Batubara, Suleman, ,Orinton Purba, Arbitrase Internasional. Raih Asa Sukses.

Buletin Len, Ed. No.15. PT Len Industri , Maret, 2014.

Christianto, Hwian. "Norma Kesusilaan Sebagai Batasan Penemuan Hukum Progresif Perkara Kesusilaan Di Bangkalan Madura". Jurnal Hukum \& Pembangunan. Tahun ke-46 No. 1. Januari-Maret, 2016.

Damaitu, Emanuel Raja. "Perbandingan Asas Perjanjian dalam Hukum Islam dan Kitab Undang-Undang Hukum Perdata". Jurnal Repertorium. 1. Januari- Juni, 2014.

Gayo, Akhyar Ari. "Dinamika Legislasi Hukum Islam: Analisa atas Upaya Pembentukan Hukum Perikatan Syariah". Jurnal RechtsVinding, Vol. 4, No. 3 .Desember, 2015.

Gegana, Giska Matahari. Penerapan Prinsip Tanggung Renteng dalam Hal Kreditur Melakukan Wanprestasi terhadap Perjanjian Kredit Sindikasi. Skripsi. Depok: Universitas Indonesia, 2011.

Hapsari, Dwi Ratna Indri. Kontrak dalam Kitab UndangUndang Hukum Perdata dan Hukum Islam". Jurnal Repertorium. 1 .Januari- Juni, 2014.

Hukum Dalam Ekonomi, ed. II. Grasindo.

Hutabarat, Samuel M. P. Penawaran Dan Penerimaan Dalam Hukum Perjanjian. Grasindo.

Indraharti, Novina Sri. "Aspek Keabsahan Perjanjian dalam Hukum Kontrak (Suatu Perbandingan antara Indonesia dan Korea Selatan". Jurnal Hukum Prioris. Vol. 4, No. 1. 2014.

Karunia, Tria. "Syarat Sahnya Perjanjian". dalam http://www.jurnalhukum.com/syarat-syarat-sahnyaperjanjian/_ akses 3 Januari 2017.

Kharisma, Dona Budi. Keabsahan dan Landasan Kekuatan Mengikat Kontrak Elektronik melalui Telemarketting Ditinjau dari Hukum Perjanjian di Indonesia. Tesis. Surakarta: Universitas Sebelas Maret, 2013. 
KUHPerdata.

Maerisa Eka Astri. Panduan Praktis Membuat Surat-Surat Bisnis E Perjanjian. VisiMedia, 2013.

Noor, Muhammad. "Penerapan Prinsip-Prinsip Hukum Perikatan dalam Pembuatan Kontrak". Mazahib. Vol. XIV. No. 1. Juni, 2015.

Panduan Bantuan Hukum di Indonesia. ed. 2006. Yayasan Obor Indonesia, 2006.

Panggabean, R.M. "Keabsahan Perjanjian dengan Klausul Baku". Jurnal Hukum. No. 4 Vol. 17. Oktober, 2010.

Pasal 1313 KUHPerdata.

Pianda, Jondra. Perjanjian dalam Perspektif Hukum Islam dan Hukum Konvensional", dalam http://jondrapianda.blogspot.co.id/2011/05/perjanjia n-dalam-perspektif-hukum-islam.html akses 7 Januari 2017.

Prasadha, Giri. "Kajian Yuridis Pelaksanaan Pelaksanaan Waralaba Pada Texas Chicken Padang". Jurnal. Padang: Universitas Taman Siswa, 2015.

Pribadi, Carina Pariska I Ketut Rai Setiabudhi, Ida Bagus Wyasa Putra. "Study of Legal Ownership of Land Juridical Property by Foreign Citizens Through The "Nominee Agreement" Which Was Made Before The Notary". Jurnal Ilmiah Prodi Magister Kenotariatan. 20132014.

Rahmasari, Dita. Analisis Yuridis Perpindahan Pemain Sepakbola berdasarkan Kitab Undang-Undang Hukum Perdata dan Peraturan Keolahragaan Lainnya. Skripsi. Depok: Universitas Indonesia, 2011.

Safira, Martha Eri. Hukum Ekonomi di Indonesia. Ponorogo: Nata Karya, 2016.

Santoso Az, Lukman. Hukum Perikatan; Teori Hukum dan Teknis Pembuatan Kontrak, Kerja sama, dan Bisnis. Malang: Setara Press, 2016.

Setiawan, Fajar Bayu, Himma Asihsalista, Nikki Ramadhani M. Pranoto. "Kedudukan Kontrak Sewa Rahim dalam Hukum Positif Indonesia". Private Law. ed. 1. MaretJuni, 2013. 
Sylviana. Tabloid Reformata. Edisi 114 TahunVII (Yayasan Pelayanan Media Antiokhia (YAPAMA ). 1-15 September, 2009.

Yessica, Evalina. "Karakteristik dan Kaitan antara Perbuatan Melawan Hukum dan Wanprestasi". Jurnal Repertorium. vol.1, no.2. November, 2014. 